\title{
Correction to: Hydrogen fuel and fuel cell technology for cleaner future: a review
}

\author{
Manish Kumar Singla ${ }^{1}$ Parag Nijhawan ${ }^{1}$. Amandeep Singh Oberoi ${ }^{2}$
}

Published online: 1 March 2021

(C) Springer-Verlag GmbH Germany, part of Springer Nature 2021

\section{Correction to: Environmental Science and Pollution Research https://doi.org/10.1007/s11356-020-12231-8}

The correct title is presented in this paper.

The original article has been corrected.

Publisher's note Springer Nature remains neutral with regard to jurisdictional claims in published maps and institutional affiliations.

The online version of the original article can be found at https://doi.org/ $10.1007 / \mathrm{s} 11356-020-12231-8$

$\triangle$ Manish Kumar Singla

msingla60_phd18@thapar.edu

Parag Nijhawan

parag.nijhawan@ rediffmail.com

Amandeep Singh Oberoi

oberoi@ thapar.edu

1 Electrical and Instrumentation Engineering Department, Thapar Institue of Engineering and Technology, Patiala, India

2 Mechanical Engineering Department, Thapar Institute of Engineering and Technology, Patiala, India 